Asian-Australasian Journal of Food Safety and Security

ISSN 2523-1073 (Print) 2523-2983 (Online)

www.ebupress.com/journal/aajfss

\title{
Article \\ An assessment of socio-economic conditions of the farmers related to goat fattening in Rangpur district of Bangladesh
}

Topon Chandra Barman ${ }^{1}$, Mohammad Mujaffar Hossain ${ }^{1}$, Md. Mukhlesur Rahman ${ }^{1}$, Md. Younus Ali ${ }^{2 *}$ and Nipa Rani Sarker ${ }^{3}$

${ }^{1}$ Department of Animal Science, Bangladesh Agricultural University, Mymensingh-2202, Bangladesh

${ }^{2}$ Goat and sheep production research division, Bangladesh Livestock Research Institute, Savar, Dhaka-1341, Bangladesh

${ }^{3}$ Department of Genetics \& Animal Breeding, Hajee Mohammad Danesh Science \& Technology University5200, Bangladesh

*Corresponding author: Md. Younus Ali, Goat and Sheep Production Research Division, Bangladesh Livestock Research Institute, Savar-1341, Bangladesh. E-mail: younus.bau@gmail.com

Received: 24 October 2017/Accepted: 06 November 2017/ Published: 21 November 2017

\begin{abstract}
The experiment was carried out at Kaunia upazila in Rangpur district to investigate the socioeconomic conditions of the farmers, use of different hormones, feed additives and their effects. The data were collected through interview schedule by selecting 30 respondents who were involved in goat fattening. Collected data were analyzed using Excel sheet. It was found that most of the farmers were middle aged categories $(50 \%)$ and educational level of the farmers was primary $(57 \%)$, secondary $(23 \%)$, and higher secondary (10\%). Half of the respondents were farmer, followed by businessman (20\%). About $67 \%$ farmers used own capital, $3 \%$ farmers took loan from bank and $23 \%$ took loan from other sources such as NGO. It was also found that about 33\% respondents had on short time training experience and the rest $67 \%$ had no experience. Almost 97\% farmers reared Black Bengal goat and 3\% Jamunapari goat. Near about 97\% farmers used roadside grass and tree leaves and only 3\% farmers used cultivated fodder. Only $7 \%$ farmer used growth promoter \& feed additives in feed where $93 \%$ farmers are not being used growth promoter \&feed additives in feed. But not a single farmer used growth hormones for fattening purpose. Therefore, still now goat meat would be safe for human consumption without any health hazard.
\end{abstract}

Keywords: goat fattening; hormones; feed additives

\footnotetext{
1. Introduction

Livestock is an integral component of agricultural economy of Bangladesh performing multifarious functions such as provision of food, nutrition, income, savings, draft power, manure, and transport, social and cultural functions. The livestock resources of Bangladesh are mainly based on cattle, goat, sheep, buffalo, and poultry. The average number of goats per household is about 2.31 in Bangladesh and they are mostly reared by landless, small and medium farmers (Faruque et al., 2010). Goat plays a vital role in the economy of poor dwellers in adverse climatic condition of Bangladesh (Kosgey, 2004) and Perry et al. (2002). Goats in communal areas are less susceptible to drought than cattle and have lower feed and capital requirement than large ruminants (Iniguez, 2004). They are better able to utilize a variety of feed stuffs, including fibrous crop residues (Holst, 1999). The domestic goat (Capra hircus) is an important livestock species in Bangladesh and has about 25.734 million in number (BER, 2015). The old man saying "The goat is the poor man's cow" (MacHugh and Bradley, 2001 ) is still hold true for developing country like Bangladesh. The increasing trends of meat consumption have already been evident in several Southeast Asian countries such as Indonesia, Malaysia, Philippines and Thailand (Skunmun et al., 2002). According to Department of Livestock Services (DLS, 2015-2016) the availability of
} 
meat is $106.21 \mathrm{~g} / \mathrm{d}$ per head against the requirements of $120 \mathrm{~g} / \mathrm{d}$ per head. So, it is clear that there is a huge shortage of meat in Bangladesh for human consumption. An increasing number of consumers demanding health and natural foods have favoured organic goat farming that is reputed to be environmentally friendly, sustaining animals in good health, with high welfare standards and resulting in high quality products (Sundrum, 2001). In many countries, growth promoting hormones have been successfully used to increase the growth rate of animals, particularly in goat. A scientific agreement was also adopted to prohibit the use of stilbenes owing to their potential tumor-inducing effects in human. However, most of these compounds have not gained widespread consumer acceptability and growth-promoting hormones were banned by the EU. The consequence of this EU position has been the development in numerous countries of a black market of hormone cocktails including potentially dangerous synthetic steroids and corticoids. The weight gain increase in steroid-treated animals was associated with net protein accretion and $\mathrm{N}$ retention without any changes in the digestibility of $\mathrm{N}$ intake (Scarth et al., 2009). In Bangladesh, feed additives and growth promoters imported by pharmaceutical industries and overseas marketing agencies and attract farmers to use them in fattening animals. Some of them may have deleterious residual effects on human health or some may not respond cost effectively. Most of the goat brought for sale as sacrificial animals in the northern districts ahead of Eid-ul-Azha are fattened allegedly by unscrupulous goat traders ignoring the scientific formula prescribed by Livestock Department. However, almost no attention has been paid in Bangladesh in respect of using hormone and feed additives in small scale goat fattening.

\section{Materials and Methods}

\subsection{Study area}

The study was conducted at Sarai, Haragachh and Kursha unions, respectively under Rangpur district.

\subsection{Farmer selection}

Respondents those are used hormones and feed additives in goat fattening were randomly chosen from each union. A total of 30 farmers (10 farmers from each union) were chosen for collecting data to fulfill the objectives.

\subsection{Preparation of interview schedule}

An interview schedule was carefully prepared keeping the objectives of the study in mind. The schedule contained closed and open form of questions.

\subsection{Methods of data collection}

Data were collected from respondents by one-to-one interview method. The relevant data for this study were collected without biasness. To obtain accuracy and reliability to data, care and caution were taken in the course of data collection. Attention was paid to the mood of farmers and cordial relationship was established among the farmers. Interviews were normally conducted in respondent's house during their leisure time.

\subsection{Parameters studied}

The interview schedule contained the following information's:

A) Socio-economic factors related to goat fattening like age of the farmers, educational level, household size, occupation, land size, source of capital, and purchase time etc.

B) Check list of goat fattening such as types of feed used, sources of feed, use of hormones and feed additives.

C) Public perception and suggestions to improve goat fattening.

\subsection{Statistical analysis}

At the end of data collection, the collected data were coded, compiled, tabulated and analysed by using Excel sheet. The qualitative data were transferred into quantitative data by appropriate scoring technique.

\section{Results and Discussion}

\subsection{Socio-economic condition of the goat farmers}

In this study some major characteristics of the respondents were selected to find out the socio-economic condition of the farmers like age of the farmers, family size, education, occupation, land size, source of capital and training. Number and percentage distribution of respondents according to their age of the farmers, family size, education, occupation, land size, source of capital and training on goat fattening are shown in Tables 1 and 2 . 


\subsubsection{Age of the farmers}

The findings indicated that the highest proportion (50\%) of the farmers in the study area was in the middle aged category compared to young aged category (30\%) and old aged category (20\%). The results of this study are similar with Rahman et al. (2012) where they reported that $45.3 \%$ farmers was in middle aged category $16.0 \%$ and $38.7 \%$ farmers was in young and old age category, respectively.

\subsubsection{Household size}

About $(47 \%)$ of the farmer had small size family, $37 \%$ medium size family and $16 \%$ in large size family. The results of this study is collaborate with Rahman et al. (2012) where they reported that $52 \%$ farmers had small size family, $31 \%$ medium and $17 \%$ farmers in large family.

\subsubsection{Land size}

The respondents were classified into four categories on the basis of total land (homestead and cultivable) such as marginal, small, medium and large farmers. About 23\% farmer's small, $17 \%$ medium and $3 \%$ farmers had large size land and the mean was 1.00 acre which is almost close to the result of Kumar (2014).

\subsubsection{Level of education}

Begum et al. (2007) reported that 20\%, 40\%, and 30\% farmers are illiterate, primary, and secondary level of education, respectively that is slightly higher than the present finding.

\subsubsection{Occupation}

Out of 30 respondents $50 \%$ are involved in agriculture, $20 \%$ in business and 3\% in government job and $27 \%$ in other job respectively. The results of this study agree with the result of Sarker (2014) who reported that 50\% farmers involved in agriculture and $23 \%$ in business and $23 \%$ in other job.

\subsubsection{Source of capital}

The source of capital for goat fattening varies from farmers to farmers. About $67 \%$ respondents used own capital for fattening purpose, $3 \%$ respondents taking bank loan and 23\% from other sources such as NGO loan and 7\% lending for fattening purpose. The results of this study are similar with Sarker (2014) where he reported that $57 \%$ used own capital, $10 \%$ used bank loan and 33\% from other sources such as NGO loan and lending for goat fattening purpose.

\subsubsection{Training}

Training experience was an important factor which enhanced the level of knowledge and improves skills on various aspects of agricultural technologies. Finding showed that $33 \%$ respondents had short time training experience usually from three to seven days in different govt. \& non-govt. organizations. Rest $67 \%$ had no experience of training on goat fattening purpose. Sarker (2014) and Hossain (2013) stated that 97\% farmers have no training experience on sheep and goat production respectively.

\subsection{Factors associated with goat fattening}

\subsubsection{Breed type}

About 97\% farmer's used Black Bengal goat (deshi) and 3\% farmer's used Jamunapari goat for goat fattening purpose. It was also found that $77 \%$ farmers reared goat at dry season and $23 \%$ farmers reared goat at rainy season and they used $100 \%$ castrated male goat for goat fattening purpose. The results of this study are similar with Sarker (2014) where he reported that the 100\% respondents have deshi goat (Table 3).

\subsubsection{Purchase time of goat}

Table 3 showed that, $83 \%$ farmers purchased goat occasionally and $17 \%$ farmers purchased goat around the year. Rahman et al. (2012) found that $13.3 \%$ farmers purchased goat around the year and $86.7 \%$ purchase goat occasionally for goat production. Almost similar result was found by Hossain (2013).

\subsubsection{Goat marketing}

About $(90 \%)$ respondents stated that they directly sold their goat to the local market. Most of the farmers reared male goat 1 to 3 years for fattening purpose on the basis of production performances, health and family condition of the farmers (Table 3 ). 
Table 1. Distribution of respondents according to age, household size and land size.

\begin{tabular}{llll}
\hline Parameter & Categories & Number of respondents & \% of total respondents \\
\hline \multirow{3}{*}{ Age (years) } & Young $(<30)$ & 09 & 30 \\
& Middle (31-50) & 15 & 50 \\
& Old age (> 50) & 06 & 20 \\
\hline \multirow{3}{*}{ Household size } & Small family $(<5)$ & 14 & 47 \\
& Medium family (6-8) & 11 & 37 \\
& Large family (>8) & 05 & 16 \\
\hline \multirow{3}{*}{ Land size (Acre) } & Marginal $(<1)$ & 17 & 57 \\
& Small $(1-3)$ & 07 & 23 \\
& Medium (3-8) & 05 & 17 \\
& Large $(>9)$ & 01 & 03 \\
\hline
\end{tabular}

Table 2. Distribution of respondents according to level of education, occupation, source of capital and training.

\begin{tabular}{llll}
\hline Parameter & Categories & Number of respondents & \% of total respondents \\
\hline \multirow{4}{*}{ Level of education } & Illiterate & 03 & 10 \\
& Primary & 17 & 57 \\
& SSC & 07 & 23 \\
& HSC & 03 & 10 \\
& Graduate & 00 & 00 \\
\hline \multirow{3}{*}{ Occupation } & Agriculture & 15 & 50 \\
& Business & 06 & 20 \\
& Govt. job & 01 & 03 \\
& Other job & 08 & 27 \\
\hline \multirow{3}{*}{ Source of capital } & Own capital & 20 & 67 \\
& Bank loan & 01 & 03 \\
& NGO loan & 07 & 23 \\
\multirow{2}{*}{ Training } & Lending & 02 & 07 \\
\hline
\end{tabular}

Table 3. Distribution of respondents according to breed type, purchase time, and marketing.

\begin{tabular}{llll}
\hline Parameter & Categories & Number of respondents & \% of total respondents \\
\hline \multirow{2}{*}{ Breed type } & Black Bengal Goat & 29 & 97 \\
& Jamunapari & 01 & 03 \\
\multirow{2}{*}{ Age } & Mixed & 00 & 00 \\
\hline \multirow{2}{*}{ Sex } & $1-1.5$ years & 25 & 83 \\
& $2-3$ years & 05 & 17 \\
\hline \multirow{2}{*}{ Body weight } & Castrated male & 30 & 100 \\
& Uncast rated male & 00 & 00 \\
\hline \multirow{2}{*}{ Purchase time } & (5-10)Kg & 05 & 17 \\
& Above 10kg & 25 & 83 \\
\hline \multirow{2}{*}{ Fattening Seasons } & Around the year & 05 & 17 \\
\multirow{2}{*}{ Marketing } & Occasionally & 25 & 83 \\
& Dry season & 23 & 77 \\
& Rainy season & 07 & 23 \\
\hline
\end{tabular}


Table 4. Distribution of respondents according to feed supplementation.

\begin{tabular}{|c|c|c|c|}
\hline Parameter & Categories & Number of respondents & \% of respondents \\
\hline \multirow{4}{*}{ Roughage } & Roadside grass & 09 & 30 \\
\hline & Cultivated fodder & 01 & 03 \\
\hline & Tree leaves & 05 & 17 \\
\hline & Tree leaves \& Roadside grass & 15 & 50 \\
\hline \multirow{3}{*}{ Concentrate } & Compound feed/pellet & 00 & 00 \\
\hline & Mixed feed & 23 & 77 \\
\hline & No & 07 & 23 \\
\hline \multirow{2}{*}{$\begin{array}{l}\text { Growth promoter \& feed } \\
\text { additives }\end{array}$} & Yes & 02 & 07 \\
\hline & No & 28 & 93 \\
\hline \multirow{2}{*}{ Growth hormones } & Yes & 00 & 00 \\
\hline & No & 30 & 100 \\
\hline
\end{tabular}

Table 5. Public perception and suggestions to improve goat fattening.

\begin{tabular}{lll}
\hline Public perception & Number of respondents & \% of total respondents \\
\hline They want to get more profit within short time & 28 & 93 \\
Feeding natural feed in low amount & 20 & 67 \\
They have less idea about health status & 15 & 50 \\
Lack of knowledge on carcinogenic effect of steroid hormone & - & - \\
Growth promoter using in wrong period & - & - \\
Harmful feed additives & - & - \\
Suggestions & 27 & \\
May be initiated training program & 25 & 90 \\
Feeding animals with balance and safe feed & 23 & 83 \\
Regular health check via veterinary services & 20 & 77 \\
Proper doses of vaccines in appropriate age & 15 & 67 \\
Organic growth promoter program & 15 & 50 \\
Improvement of farmer background knowledge & 12 & 50 \\
Strengthening rules and policy development for local authority & - & 40 \\
Create goat management knowledge bank & - & - \\
Knowledge bank through ICT program & - \\
\hline
\end{tabular}

\subsubsection{Livestock rearing practices}

Table 4 showed that most of the farmers used both roadside grass and tree leaves for feeding where different concentrates feed like wheat bran, rice polish or rice barn bran, kheshari bran, till oil cake, mustard oil cake, broken rice, salt etc. also used for goat fattening. These concentrate ingredients were produced by farmers and some farmers also bought from local market. About $7 \%$ farmer used growth promoter and feed additives in feed and 93\% farmers are not being used growth promoter and feed additives in feed for goat fattening. Kumar (2014) reported that about $96 \%$ farmers used roadside grass and tree leaves and only $4 \%$ farmers used cultivated fodder which is nearly similar with the result of present findings.

\subsection{Public perception and suggestions}

About $93 \%$ farmers want to get more profit within short time, $67 \%$ farmers fed natural feed in low amount, and $50 \%$ farmer have less idea about health status. The need of may be initiated training program, feeding animals with balance and safe feed, regular health check via veterinary services, proper doses of vaccines in appropriate age, organic growth promoter program, improvement of farmer background knowledge, and Strengthening rules and policy development for local authority were the most important suggestions by $90,83,77,67,50,50$ and $40 \%$ of the respondents, respectively (Table 5).

The suggestion of this study has concluded that goat-rearing has tremendous potential for improving the food, employment and livelihood security of rural people. However, a holistic livestock policy and consistent efforts are required to minimize technological knowledge gap on improved goat management practices. Due to weak economic base of goat farmers, they may be provided initial support for input supply to realize the benefits through increased adoption of innovations and technologies. The goat-based integrated livelihood models have been suggested for different categories of households in rural areas. The capacity building of goat-keepers is necessary to bring a change in goat-keepers orientation, attitude and approach. Active support services, 
availability of key inputs (vaccines, breeding bucks etc.) and a policy support for better access to micro-credit will have to be ensured for making goat farming a key tool to alleviate poverty, check migration, provide employment, manage malnutrition and attract youths for making agriculture and livestock farming more profitable even in less fertile areas.

\section{Conclusions}

The study reveal that most of the respondents were middle aged female belong to marginal class, involved in agriculture, used own capital, had no training experience on goat fattening, all the farmers used $100 \%$ castrated male Black Bengal goat and only few farmers used growth promoter and feed additives in feed. It clearly indicates that goat fattening is the most profitable and socially acceptable income generating activity and goat meat is safe for health.

\section{Conflict of interest}

None to declare.

\section{References}

Begum MAA, MM Hossain, M Khan, MM Rahman and SME Rahman, 2007. Cattle fattening practices of selected farmers in Panchagarh district. Bang. J. Anim. Sci., 36: 62-72.

Bangladesh Economic Review, 2015. Ministry of Planning, Government of the People's Republic of Bangladesh.

Department of Livestock Services, 2016. General information related to livestock. Monthly Fisheries and Livestock Bulletin, published by Fisheries and Livestock information office, Khamarbari, Farmgate, Dhaka, Bangladesh.

Faruque S, SA Chowdhury, NU Siddiquee and MA Afroz, 2010. Performance and genetic parameters of economically important traits of Black Bengal goat. J. Bang. Agri. Uni. Res. Sys., 8: 67-78.

Holst PJ, 1999. Recoding and on-farm evaluation and monitoring. In: breeding and selection. Small Ruminant Res., 34: 197-202.

Hossain MD, 2013. Present status of organic Beef Cattle Production in Shahjadpur Upazila of Sirajgong District.MS thesis, Department of Animal Science, Faculty of Animal Husbandry, Bangladesh Agricultural University, Mymensingh.

Iniguez L, 2004. Goats in resource-poor systems in the dry environments of West Asia, Central Asia, and the Inter-Andean Valleys. Small Ruminant Res., 51: 137-144.

Kosgey IS, 2004. Breeding objectives and breeding strategies for small ruminants in the tropics, PhD Thesis, Wageningen University, Netherland. pp. 272.

Kumar A, 2014. Present status of organic goat production at Bhaluka upazila in Mymensigh District. MS thesis, Department of Animal Science, Bangladesh Agricultural University, Mymensingh.

MacHugh DE and DG Bardley, 2001. Livestock genetic origin: Goats and buck the trend. Proceedings of the National Academy of Science, United State of America, 98: 5382-5384.

Perry BTF, JJ Randolf, McDermont, KR Sones and PK Thornton, 2002. Investing in animal health research to alleviate poverty. International Livestock Research Institute, Nairobi, Kenya. pp. 148.

Rahman Z, MM Hossain and MA Hashem, 2012. Cattle fattening program in Dinajpur district of Bangladesh. Progressive Agriculture, 23: 1-13.

Sarker AK, 2014. Present status of organic Sheep Production at Ramgoti Upazila in Lakshmipur District.MS Thesis, Department of Animal Science, Faculty of Animal Husbandry, Bangladesh Agricultural University, Mymensingh.

Scarth J, C Akre, L van Ginkel, B Le Bizec, H De Brabander, W Korth, J Points, P Teale and J Kay, 2009. Presence and metabolism of endogenous androgenic Anabolic steroid hormones in meat-producing animals: a review. Food Addit Contam Part a Chem Anal Control Expo Risk Assess. 26: 640-71.

Skunmun P, C Chantalakhana, R Pungchai, T Poondusit and P Prucsasri, 2002. Comparative Feeding of Nale Dairy, Beef Cattle and Swamp Buffalo. Economics of Beef Production. Asian-Australas. J. Anim. Sci., 15: 878-883.

Sundrum A, 2001. Organic livestock farming: a critical review. Live. Prod. Sci., 67: 207-215. 